ISSN 0258-7122 (Print), 2408-8293 (Online)

Bangladesh J. Agril. Res. 43(3): 407-416, September 2018

\title{
GENETIC VARIABILITY, HERITABILITY AND CORRELATION PATH ANALYSIS IN MUNGBEAN (Vigna radiata L.WILCZEK)
}

\author{
M. G. AZAM ${ }^{1}$, M. A. HOSSAIN ${ }^{2}$, M. S. ALAM ${ }^{3}$ \\ K. S. RAHMAN ${ }^{4}$ AND M. HOSSAIN ${ }^{5}$
}

\begin{abstract}
The success of crop improvement program largely depends on the nature and magnitude of genetic variability, heritability and characters association. This experiment was undertaken to estimate the extent of genetic variability and relation between yield and related characters. Twenty eight mungbean genotypes were grown at Pulses Research Centre, Ishurdi, Pabna during kharif-I 2015 in a randomized complete block design with three replications to estimate the extent of genetic variability and association between yield and yield related traits. Analysis of variance revealed that all the traits showed highly significant difference among genotypes except seeds per pod. Pods per plant, plant height and 100 seed weight showed high genotypic coefficients of variation (GCV) and phenotypic coefficients of variation (PCV). High broadsense heritability coupled with moderate genetic advance as percent of mean was observed for 100 seed weight, days to flower and pods per plant suggesting preponderance of additive gene action for these characters and selection of such traits might be effective for the improvement of grain yield. Seeds per pod, plant height and pods per plant showed positive significant phenotypic and genotypic correlation with yield. The result of path analysis indicated that pods per plant had maximum direct effect on yield followed by plant height and 100 seed weight and they contribute $31 \%$ variation in yield.
\end{abstract}

Keywords: Mungbean (Vigna radiata), variability, correlation, path analysis and yield performance.

\section{Introduction}

Mungbean (Vigna radiata L.Wilczek) is one of the most important pulse crop in Bangladesh for its easy digestibility and contains high protein. In Bangladesh, the total pulse production as per BBS 2017 it is 0.377 million ton on 0.371 million hectares with an average productivity of $1000 \mathrm{~kg} / \mathrm{ha}$ (BBS, 2017). During 201617 the total area under mungbean cultivation was 0.32 million hectare with an average productivity of $663 \mathrm{~kg} / \mathrm{ha}$ (Krishi diary, 2018). Its ranks $3^{\text {rd }}$ position in acreage among the pulse crops in our country. Low yield as well as poor stability remains one of the most important constraints in its expansion. Since, it is a short

${ }^{1}$ Scientific Officer, Pulses Research Centre, Bangladesh Agricultural Research Institute (BARI), Ishurdi, Pabna, ${ }^{2}$ Principal Scientific Officer, Pulses Research Centre, BARI, Ishurdi, Pabna, ${ }^{3}$ Senior Scientific Officer, Pulses Research Centre, BARI, Ishurdi, Pabna, ${ }^{4}$ Scientific Officer, ASICT Division, BARI, Gazipur, ${ }^{5}$ Director, Pulses Research Centre, BARI, Ishurdi, Pabna, Bangladesh. 
duration legume, it fits well in many cropping systems under rainfed and irrigated conditions and increase small farmer's income and improve soil fertility.

Estimation of genetic parameters of mungbean genotypes can act as a useful guide to suggest effective breeding procedures for improvement of quantitatively inherited characters. Hence, the information on the relative magnitude of genotypic and phenotypic coefficients of variability and character associations is of immense value in starting a scientific breeding program. The knowledge of heritability and genetic advance guide the breeders to select superior parents to initiate effective and fruitful crossing program. In mungbean large amount of genetic variability has been reported (Pandiyan et al., 2006; Ghosh and Panda, 2006), which indicates the potential for genetic improvement. Correlation coefficient analysis is a handy technique, which elaborates the degree and extent of relationship among important plant characters and it provides basic criteria for selection which leads to directional model based on yield and its components in the field experiments. Path coefficient analysis is an efficient statistical technique specially designed to quantify the interrelationship of different components and their direct and indirect effects on yield.

Crop improvement through successful selection program is only achieved using valid information about the correlation and genetic variability of traits of interest and it knows that improvement in any crop is dependent on the amount of genetic variability in the population. Therefore the aim of this study is to assess genetic variability for yield and related traits and estimate the extent of correlation between pairs of characters at genotypic and phenotypic level.

\section{Materials and Methods}

The experiment was conducted at Pulses Research Centre, Ishurdi, Pabna during kharif-I 2015 in a randomized complete block design with three replications. Sowing was done in the field on 5 March 2015. Plant to plant and row to row distances were maintained at $5 \mathrm{~cm}$ and $40 \mathrm{~cm}$, respectively. The unit plot size was 4 meter long with 4 crops. Intercultural operation (Weeding, thinning, pesticide spray) were done 20 days after seed sowing. Twenty eight genotypes were evaluated for variation in the study. Data were collected on days to flowering (DF), days to maturity (DM), pods per plant (PP), plant height (PH), number of seeds per pod (SPP), 100 seed weight (SW) and yield (Y).

Statistical Analysis: The analysis of variance, correlation and path coefficient analysis for each characteristic was performed using STAR 2.0.1(2014) software developed by IRRI and Microsoft Excel.

Estimation of variance components: The genotypic and phenotypic components of variance were computed according to formulae given by (Lush, 1949) and (Choudhary and Prasad, 1968) for the observed characteristics. The 
phenotypic and genotypic co-efficient of variations were estimated according to the formula suggested by (Burton and Devane, 1953).

Genotypic variance $\left(\sigma^{2} \mathrm{~g}\right)=\frac{\text { Genotype Mean Square }(\mathrm{GMS}) \text { - Error Mean Square (EMS) }}{\text { Number of Replication }(\mathrm{r})}$

Phenotypic Variance $\left(\sigma^{2} p\right)=\sigma^{2} g+\sigma^{2} e$

Genotypic co-efficient of variation $(\mathrm{GCV})=\frac{\sqrt{\sigma}^{2} g}{\overline{\mathrm{x}}} \times 100$

Phenotypic co-efficient of variation $(\mathrm{PCV})=\frac{\sqrt{\sigma}^{2} p}{\overline{\mathrm{x}}} \times 100$

Estimation of heritability: Broad sense heritability measures the extent to which phenotypic variation is determined by genotypic variation. Heritability was estimated in broad sense by the formula suggested by Johnson et al. (1955) as:

Heritability $\left(\mathrm{h}^{2} \mathrm{~b}\right)=\frac{\sigma^{2} g}{\sigma^{2} p} \times 100$

Estimation of genetic advance: Estimation of genetic advance and percentage of the mean (GAM) was done following formula illustrated by Johnson et al., (1955) as:

Genetic Advance $(\mathrm{GA})=\mathrm{h}_{\mathrm{b}}^{2}$. K. $\sigma \mathrm{p}$

Where,

$\mathrm{h}^{2} \mathrm{~b}=$ Heritability

$\mathrm{K}=$ Selection differential, the value of which is 2.06 at $5 \%$ selection intensity and $\sigma \mathrm{p}=$ Phenotypic standard deviation.

The genetic advance percentage of mean (GAM) was computed as:

$\operatorname{GAM}(\%)=\frac{G A}{\bar{x}} \times 100$

\section{Estimation of correlation coefficients:}

The Genotypic and phenotypic correlation coefficients between yield and different yield contributing characters were estimated as following Singh and Choudhury (1985) as:

Genotypic correlation $\left(\mathrm{r}_{\mathrm{g}}\right)=\frac{\operatorname{Cov}(p h) x y}{\sqrt{\sigma^{2}(p h) x \sigma^{2}(p h) y}}$

Similarly,

Phenotypic correlation $\left(\mathrm{r}_{\mathrm{p}}\right)=\frac{\operatorname{Cov}(p h) x y}{\sqrt{\sigma^{2}(p h) x \sigma^{2}(p h) y}}$ 
Estimation of direct and indirect effect of different characters on yield: The path coefficient analysis was done according to the method of Dewey and Lu (1959).

Calculation of residual effect: After calculating the direct and indirect effect of different traits, the Coefficient of determination $\left(\mathrm{R}^{2}\right)$ and residual effect $(\mathrm{U})$ was calculated using the formula suggested by (Singh and Choudhury, 1985) as:

$\mathrm{U}=\sqrt{1-R^{2}}$

Where, $\mathrm{R}^{2}=\sum r_{i j} p_{i j}$

\section{Results and Discussion}

Analysis of variance: The analysis of variance for all characters is presented in Table 1. It revealed highly significant $(\mathrm{p}<0.01)$ differences for all characters except for number of seeds per plant that had non-significant differences among the genotypes. This suggested adequate amount of genetic variability among genotypes that may be helpful for yield improvement by selection. Similar results have also been reported to have highly significant variations with regard in different sets of mungbean genotypes (Abbas et al., 2008; Abbas et al., 2010; Rahim et al., 2010; Mondal et al., 2011).

Table 1. Analysis of variance of seven yield contributing characters in respect of 28 mungbean genotypes

\begin{tabular}{l|c|c|c|c|c|c|c|c}
\hline \multirow{2}{*}{$\begin{array}{c}\text { Sources } \\
\text { of } \\
\text { variation }\end{array}$} & DF & \multicolumn{7}{|c}{ Mean sum of squares } \\
\cline { 3 - 9 } & DF & DM & PH & PP & 100 SW & SPP & Y \\
\hline Replication & 2 & 1.2262 & 1.1071 & 51.9925 & 47.3787 & 0.2448 & 37.7976 & 699766.3 \\
Genotype & 27 & $49.906^{* *}$ & $21.494 * *$ & $296.078^{* *}$ & $115.308^{* *}$ & $2.357 * *$ & $53.754^{\mathrm{ns}}$ & $477653.70^{* *}$ \\
Error & 54 & 1.4237 & 1.4405 & 24.481 & 25.1578 & 0.0666 & 46.1433 & 137956.6 \\
$\mathrm{CV}(\%)$ & - & 3.00 & 1.85 & 10.08 & 15.13 & 5.56 & 13.51 & 10.35 \\
\hline
\end{tabular}

$\mathrm{DF}$ - Degree of freedom, * - Significant at $\mathrm{p}=0.05$, ** - Significant at $\mathrm{p}=0.01, \mathrm{DF}=$ Days to flowering, $\mathrm{DM}=$ Days to maturity, $\mathrm{PH}=\mathrm{Plant}$ height $(\mathrm{cm}), \mathrm{PP}=$ Number of Pods per plant, $\mathrm{SPP}=$ No. seed per pod, $100 \mathrm{SW}=$ Hundred seed wt. $(\mathrm{g})$ and $\mathrm{Y}=$ Seed yield (Kg/ha)

Genetic components: Genotypic variance, genotypic coefficient of variance, phenotypic variance, phenotypic coefficient of variance, broad sense heritability and genetic advance for seven traits were shown in Table 2. The knowledge of nature and magnitude of the variability among the accessions for the traits is very important prerequisite for making simultaneous selection on more number of traits to make significant improvement in mungbean. The genotypic and phenotypic variance ranged from 0.58 and 0.64 for 100 seed weight and 84924.27 to 222880.84 for yield, respectively. Estimates of both genotypic and 
phenotypic variances were high for yield, plant height and pods per plant (Table 2). Coefficient of variation was estimated at phenotypic and genotypic levels. In general, phenotypic coefficient of variation was higher in magnitude than that of genotypic coefficient for all the characters. The highest values of coefficient of variation were recorded for pods per plant i.e., 23.79 and 34.61 in percent followed by yield (18.33 and 29.69), plant height (16.79 and 19.59) and 100 seed weight (16.42 and 17.35) at genotypic and phenotypic levels, respectively. The lowest value of coefficient of variation was found for days to maturity at both genotypic and phenotypic levels. The highest estimate of coefficient of variation was recorded for pods per plant followed by yield, plant height and 100 seed weight. The differences of phenotypic and genotypic variances were also found low for the characteristics of days to maturity, days to flower and 100 seed weight, indicated that these characteristics were less influenced by environment, while and rest of the traits were influenced by environment. Reddy et al., (2003), Pandiyan et al., (2006), Rahim et al., (2010) and Rai et al., (2014) also reported the similar results in their findings.

Heritability: Heritability estimates are classified by Burton (1952) as high (greater than 70\%), moderate (50-70\%) and low (less 50\%). The magnitude of the estimated broad sense heritability in this study ranged from 37.74 for seeds per pods to 89.58 for 100 seed weight. 100 seed weight showed the highest (89.58) broadsense heritability followed by days to flower (89.49) pods per plant (81.25) and days to maturity (77.69), whereas, the lowest values of heritability were obtained for seeds per pods (37.74) and yield (38.11) and rest of the traits showed moderate heritability. Heritability estimates were high for pods per plant, 100 seed weight and seed yield per plant. The characters which exhibited high heritability suggests that the selection will be more effective whereas the traits showing low heritability indicates that the selection will be influenced by the environmental factors.

Genetic advance: The highest amount of genetic advance was observed for yield (370.56) followed by plant height (14.557), days to flower (6.79) and pods per plant (6.727). On the other hand, the lowest amount of genetic advance was recorded for seeds per pod (0.57) and 100 seed weight (1.48). Similar results were reported by Reddy et al., (2003), Pandiyan et al., (2006), Gul et al., (2007) and Rahim et al., (2010). High heritability coupled with high genetic advance for 100 seed weight, days to flower and pods per plant indicated the role of additive gene action in their expression; suggesting that these traits are responsive in early generation selection. High heritability coupled with low genetic advance for days to maturity indicating the presence of additive as well as non-additive gene action. For these traits improvement can be made opting the two to three cycles of recurrent selection followed by pedigree or single seed descent methods of breeding as also corroborated by the findings of Pandiyan et al. (2006); Dadepeer et al. (2009), Dhananjay et al. (2009) and Rahim et al. (2010). 
Table 2. Genetic variability components for different quantitative traits in mungbean

\begin{tabular}{l|c|c|c|c|c|c|c}
\hline \multicolumn{1}{c}{ Characters } & $\begin{array}{c}\text { Grand } \\
\text { mean }\end{array}$ & $\sigma^{2} \mathrm{~g}$ & $\sigma^{2} \mathrm{p}$ & $\begin{array}{c}\mathrm{GCV} \\
(\%)\end{array}$ & $\begin{array}{c}\mathrm{PCV} \\
(\%)\end{array}$ & $\mathrm{h}_{\mathrm{b}}^{2}(\%)$ & $\mathrm{GA}$ \\
\hline Days to flower & 39.73 & 12.120 & 13.55 & 8.76 & 9.26 & 89.49 & 6.79 \\
Days to maturity & 64.82 & 5.013 & 6.46 & 3.46 & 3.92 & 77.689 & 3.07 \\
Plant height (cm) & 49.07 & 67.89 & 92.38 & 16.796 & 19.59 & 68.51 & 14.557 \\
Pods per plant No.) & 19.96 & 22.54 & 47.69 & 23.79 & 34.61 & 81.25 & 6.727 \\
100 seed weight (g) & 4.61 & 0.58 & 0.64 & 16.42 & 17.35 & 89.58 & 1.48 \\
Seeds per pod (No.) & 50.27 & 1.91 & 48.05 & 3.75 & 13.79 & 37.74 & 0.57 \\
Yield (Kg/ha) & 1590.39 & 84924.27 & 222880.84 & 18.33 & 29.69 & 38.11 & 370.56 \\
\hline
\end{tabular}

Genotypic and phenotypic correlations: The genotypic and phenotypic association of seed yield with other characters is presented in Table 3. The relationship among these characters and their association with seed yield is essential to establish selection criteria (Singh, 1990). Seed yield had positive and highly significant genotypic correlation with plant height (0.482), pods per plant (0.491) and seeds per pod (0.641). Plant height, pods per plant and seeds per pod showed significant and positive phenotypic correlation with yield. A highly significant positive association between days to flowering and days to maturity was observed both at genotypic (0.855) and phenotypic (0.713) levels. The result revealed that if days to flowering increased, then days to maturity and plant height also increased. Days to flowering showed a highly significant negative association with 100 seed weight both at genotypic (-0.596) and phenotypic (-0.534) level. Days to maturity also showed a highly significant negative association with 100 seed weight and seeds per pod both at genotypic and phenotypic levels. Plant height had a significant positive correlation with yield and number of seeds per pod at genotypic level and phenotypic level. Makeen et al. (2007), Islam et al., (1999), Niazi et al., (1999) also observed a significant positive correlation between plant height and seed yield. Pods per plant showed a significant positive correlation with seed per pod and seed yield both at genotypic and phenotypic levels as reported by Makeen et al. (2007), Rao et al. (2006), Islam et al. (1999). Seeds per pod showed significant positive correlation with seed yield both at genotypic (0.641) and at phenotypic (0.379) level. Similar results were obtained by Islam et al. (1999). Highly significant positive correlation was recorded between 100 seed weight and seeds per pod at genotypic (0.612) and phenotypic (0.576) levels. 
Table 3. Estimates of genotypic $\left(r_{g}\right)$ and phenotypic $\left(r_{p}\right)$ correlation coefficients among different quantitative characters in mungbean.

\begin{tabular}{|c|c|c|c|c|c|c|c|}
\hline Characters & & DF & $\mathrm{DM}$ & $\mathrm{PH}(\mathrm{cm})$ & PP (No.) & $100 \mathrm{SW}(\mathrm{g})$ & SPP (No.) \\
\hline \multirow{2}{*}{ Days to flower } & $\mathbf{r g}_{\mathrm{g}}$ & - & & & & & \\
\hline & $\mathbf{r}_{\mathbf{p}}$ & - & & & & & \\
\hline \multirow{2}{*}{ Days to maturity } & $\mathbf{r g}_{\mathrm{g}}$ & $0.855 * *$ & & & & & \\
\hline & $\mathbf{r}_{\mathbf{p}}$ & $0.713 * *$ & & & & & \\
\hline \multirow{2}{*}{ Plant height $(\mathrm{cm})$} & $\mathbf{r}_{\mathrm{g}}$ & 0.227 & $0.399 * *$ & & & & \\
\hline & $\mathbf{r}_{\mathbf{p}}$ & 0.184 & 0.208 & & & & \\
\hline \multirow{2}{*}{ Pods per plant (No.) } & $\mathbf{r g}_{\mathrm{g}}$ & 0.231 & 0.219 & -0.359 & & & \\
\hline & $\mathbf{r}_{\mathbf{p}}$ & 0.150 & 0.133 & -0.212 & & & \\
\hline \multirow{2}{*}{100 seed weight $(g)$} & $\mathbf{r g}_{\mathrm{g}}$ & $-0.596 * *$ & $-0.605^{* *}$ & -0.284 & 0.221 & & \\
\hline & $\mathbf{r}_{\mathbf{p}}$ & $-0.534 * *$ & $-0.505^{* *}$ & -0.231 & 0.144 & & \\
\hline \multirow{2}{*}{ Seeds per pod (No.) } & $\mathbf{r g}_{\mathrm{g}}$ & -0.004 & $-0.731 * *$ & $0.618 * *$ & $0.715 * *$ & $0.612 * *$ & \\
\hline & $\mathbf{r}_{\mathbf{p}}$ & -0.001 & $-0.582 * *$ & $0.538 * *$ & $0.526^{* *}$ & $0.576 * *$ & \\
\hline \multirow{2}{*}{ Yield (Kg/ha) } & $\mathbf{r g}_{\mathrm{g}}$ & 0.251 & 0.013 & $0.482 * *$ & $0.491 * *$ & -0.011 & $0.641 * *$ \\
\hline & $\mathbf{r}_{\mathbf{p}}$ & 0.183 & 0.011 & $0.373^{*}$ & $0.394^{*}$ & -0.015 & $0.379 *$ \\
\hline
\end{tabular}

* - Significant at $\mathrm{p}=0.05, * *$ - Significant at $\mathrm{p}=0.01$

Path analysis: The correlation values indicate only the nature and degree of association existing between pairs of characters. A character like seed yield is dependent on several mutually associated component characters and change in any one of the components is likely to affect the whole network of cause and effect relationship. This in turn might affect the true association of component characters, both in magnitude and direction and tend to vitiate association of yield and yield components.

Path coefficient analysis revealed that number of pods per plant, had the maximum direct effect (0.408) on seed yield followed by plant height and 100 seed weight. It indicated that a slight increase in any of these traits may directly contribute towards seed yield (Table 4). Pods per plant showed positive direct effect of on seed yield via indirect positive effect through days to flowering, days to maturity and plant height. Our findings are in accordance with previous reports (Rao et al., 2006; Makeen et al., 2007; Hakim, 2008; Tabasum et al., 2010 and Mondal et al., 2011). Positive direct effect of plant height on seed yield and indirect positive effects via days to maturity and 100 seed weight as observed in this study have also been reported by Solanki (2006) and Tyagi and Khan (2011). Moreover, 100 seed weight exhibited positive indirect effects through days to maturity, seeds per pod and plant height. Similar findings were also reported by Mondal et al., (2011) and Biradar (2007). The residual effect of 0.69 was 
observed under present study indicates the contribution of component characters was $31 \%$ and the rest $69 \%$ was the contribution of other factors. The present study suggests that seed yield, number of pods per plant and plant height are greatly influenced by the additive gene effect and greater proportion of variations are heritable.

Table 4. Direct (diagonal) and indirect effects (off-diagonal) of different characters on yield at genotypic level

\begin{tabular}{l|c|c|c|c|c|c|c}
\hline & DF & DM & PH & PP & 100 SW & SP & Y \\
\hline DF & $\mathbf{- 0 . 4 9 9}$ & -0.655 & -0.461 & 0.164 & 0.012 & 0.612 & 0.251 \\
DM & -0.655 & $\mathbf{- 0 . 0 9 8}$ & 0.591 & 0.156 & 0.147 & -0.423 & 0.013 \\
PH & -0.461 & 0.591 & $\mathbf{0 . 3 8 3}$ & 0.275 & 0.14 & -0.429 & $0.482^{* *}$ \\
PP & 0.164 & 0.156 & 0.275 & $\mathbf{0 . 4 0 8}$ & -0.228 & -0.201 & $0.491^{* *}$ \\
100 SW & 0.012 & 0.147 & 0.14 & -0.228 & $\mathbf{0 . 1 2 4}$ & 0.144 & -0.011 \\
SP & 0.612 & -0.423 & -0.429 & -0.201 & 0.144 & $\mathbf{- 0 . 0 7 8}$ & $0.641^{* *}$ \\
\hline
\end{tabular}

$\mathrm{R}^{2}=0.323$

$\mathrm{DF}=$ Days to flowering, $\mathrm{DM}=$ days to maturity, $\mathrm{PH}=$ Plant height $(\mathrm{cm}), \mathrm{PP}=$ Number of Pods per Plant, SPP= No. seed per pod, 100SW= Hundred seed wt. $(\mathrm{g})$ and $\mathrm{Y}=$ yield.

\section{References}

Abbas, G., M. J. Asghar, T. M. Shah and B. M. Atta. 2010. Genetic diversity in mungbean [(Vigna radiata (L.) Wilczek] germplasm. Pak. J. Bot. 42:3485-3495.

Abbas, G., B. Manzoor, T. Mahmood, M. Siddique, and M. Ahsanul Haq. 2008. Stability analysis for seed yield in mungbean [Vigna radiata (L.)Wilczek]. J. Agri. Res. 46:223-228.

BBS. 2017. Bangladesh Bureau of Statistics. Statistical Yearbook of Bangladesh. Statistics Division, Ministry of Planning, GOB.

Biradar, K. 2007. Genetic studies in green gram and association analysis. Karnataka J. Agri. Sci. 20:843-844.

Burton, G. W. 1952. Quantitative inheritance in grasses. Proceedings of the 6th International grassland Congress, August 17-23, 1952, Pensylvania State College, USA., pp:277-283.

Burton, G. W. and E. H. De Vane. 1953. Estimating heritability in tall fescue (Festuca arundinacea) from replicated clonal material. Agro. J. 45: 478-481.

Choudhary, L. B. and B. Prasad. 1968. Genetic variation and heritability of quantitative characters in Indian Mustard (Brassica juncea L. Czern and Coss). Indian J. Agric. Sci. 38: 820-825. 
Dadepeer, P., R. L. Ravi Kumar and P. M. Salimath. 2009. Genetic variability and character association in local green gram genotypes. Environment and Ecology. 27(1): 165-169.

Dewey, D. R. and K. H. Lu.1959, A correlation and path co-efficient analysis of components of crested wheat grass seed production. Agron. J. 51: 515-518.

Dhananjay, R., B. N. Singh and G. Singh. 2009. Studies on genetic variability, correlations and path coefficients analysis in mung bean. Crop Res. Hisar. 38(1/3): 176-178.

Ghosh, A. and S. Panda. 2006. Association and variation studies between grain characteristics and germination of mungbean (Vigna radiata L. wilczek). Legume res. 29: $118-121$.

Gul, R. S. Ali, H. Khan, F. Nazia, I. Ali. 2007. Variability among mungbean (Vigna radiata) genotypes for yield and yield components grown in peshawar valley. J. Agri. and Biol. Sci. 2(3):54-57.

Hakim, L. 2008. Variability and correlation of agronomic characters of mungbean germplasm and their utilization for variety improvement programme. Indonesian $J$. Agri. Sci. 9:24-28.

Islam, M. T., M. M. Haque, M. O. Islam, M. A. Malek and M. E. Hoque.1999. Genetic variability, correlation and path analysis in mungbean (Vigna radiata) L. Wilczek. Bang. J. Sci. and Indust. Res. 34(1): 103-107.

Johnson, H. W. H. F. Robinson and R. F. Comstock. 1955. Estimates of genetic and environmental variability in soybeans. Agron. J. 47: 310-318.

Krishi Diary. 2017. Agricultural Information Service (AIS). Ministry of Agriculture. GoB. Dhaka, Bangladesh.

Lush, J. L. 1949. Heritability of quantitative characters in farm animals. Hereditas. suppl. 356-375.

Makeen, K., G. Abrahim, A. Jan and A. K. Singh. 2007. Genetic variability and correlations studies on yield and its components in mungbean (Vigna radiata (L.) Wilczek). J. Agron. 6:216-218.

Mondal, M. M. A., M. A. Hakim, A. S. Juraimi, M. A. K. Azad and M. R. Karim.2011. Contribution of morpho-physiological attributes in determining the yield of mungbean. African J. Biotechnol. 10:12897-12904.

Niazi, N.1999. Path-coefficient analysis of agronomic characters affecting seed yield in Vigna radiata (L.) Wilczek. J. Genetics and Breeding. 53(1): 63-65.

Pandiyan, M. B. Subbalakshasmi and S. Jebaraj. 2006. Genetic variability of green gram. Int. J. Plant Sci. 1:72-75.

Rahim, M. A., A. A. Mia, F. Mahmud, N. Zeba and K. S. Afrin. 2010. Genetic variability, character association and genetic divergence in mungbean (Vigna radiata (L.) Wilczek). Plant Omics. 3(1): 1-6.

Rai, P. K., A. Kumar, B. A. Singh and A. K. Chaurasia. 2014. Study on the performance of groundnut (Arachis hypogea L.) genotypes for quantitative traits in Allahabad region. Carib. J. SciTech. 2: 564-569. 
Rao, C. H., M. Rao, Y. Koteswara and M. Reddy. 2006, Genetic variability and path analysis in mungbean. Legume Res. 30: 216-218.

Rao, G. R., Y. K. Rao, and C. M. Rao. 2006. Genetic divergence in mungbean. Indian J. Pulses Res. 19: 61-63.

Reddy, V. L. N., M. Reddi Sekhar, K. R. Reddy and K. H. Reddy. 2003. Genetic variability for yield and its components in mungbean [Vigna radiata (L.) Wilczek]. Legume Res. 26(4): 300-302.

Singh, B. D. 1990. Plant Breeding: Principles and Methods. Kalyani Publishers, New Delhi

Singh, R. K. and B. D. Choudhury. 1985. Biometrical methods in quantitative genetic analysis. Kalyani Publishers, New Delhi, pp: 102-138.

Solanki, Y. S. 2006. Comparison of correlations and path coefficients under environments in lentil (Lens culinaris Medik). Crop Improv. 33: 70-73.

STAR, version 2.0.1. 2014. Biometrics and Breeding Informatics, PBGB Division, International Rice Research Institute, Los Baños, Laguna.

Tabasum, A., M. Saleem and I. Aziz 2010. Genetic variability, trait association and path analysis of yield and yield components in mungbean (Vigna radiata (L.) Wilczek). Pak. J. Bot. 42: 3915-3924.

Tyagi, S. D. and M. H. Khan. 2011. Correlation, path-coefficient and genetic diversity in lentil (Lens culinaris Medik) under rainfed conditions. Inter. Res. J. Plant Sci. 2: 191-200. 